onized nation of the Philippines (84). The racial classifications of the white oligarchy impacted how workers saw each other and themselves, influencing the kinds of struggles they waged (i.e., ethnic-specific labour associations) and their strategic thinking about how to unite against a common enemy. Thus, from the mid-1800s to the early 1940s, workers struggled among themselves over racial classifications like coolie, cheap labor, citizen, haole, and American, "defining what these categories meant and who belonged to them" (188). To unite together, workers of different ethnic groups needed to confront and overcome qualitatively different racial inequalities.

According to Jung, during World War II and the immediate years preceding it, new "mobilizing structures" and "political opportunities" enabled workers to transform their thinking about race and class (107). In this period, workers took advantage of New Deal legislation and the coming of the National Labor Relations Board (NLRB) to Hawaii. Longshoremen in the islands gained resources and new approaches to organizing from their contact with West Coast counterparts. Japanese Americans fought valiantly in World War II, shifting perception in the islands of their loyalty.

The impact of these developments culminated in the 1946 strike. For Jung, the strike represented for workers a new understanding of racial justice as encompassing united worker power. In other words, workers defined the strike as not simply an economic struggle - i.e., a campaign for better wages and working conditions and union power - but as part of the historical struggle of workers in the islands against racial discrimination and for the rights of immigrants against a common oppressor.

Can Jung's insights about the relationship of race and class be applied to other multiracial settings, beyond colonial Hawaii? Most definitely. However, the crucial starting point is for labour historians and social scientists - as well as labour and community organizers - to discard the predominant framework of "deracialization" and to understand that the making of a working class integrally involves racial justice.

Glenn Omatsu

California State University, Northridge

\title{
Neil Foley, Quest for Equality: The Failed Promise of Black-Brown Solidarity (Cambridge: Harvard University Press, 2010).
}

Race relations between African Americans and Mexican Americans are commanding greater attention from scholars. Both racial groups have comprised key constituencies of the American left during the twentieth century. A contributor to the Du Bois Institute of African and African American Research Nathan Huggins' Lecture Series, Neil Foley's Quest for Equality explains the historical failure of Black- 
Brown racial solidarity in the post-World War II civil rights era. Foley argues that Mexican Americans' embrace of whiteness blocked any meaningful political solidarity between these racial groups, despite experiencing an often-convergent history of racial discrimination. Mexican American civil rights leaders strategically avoided civil rights alliances with African Americans on issues pertinent to racial identity. Foley's previous scholarship has been critical in integrating whiteness studies in the field of Chicana/o history, specifically his suggestion that Hispanics' Faustian pact with whiteness "reinforced the color line rather than crossed or subverted it.” (14)

Arranged in three chapters including a lengthy introduction and epilogue, Foley's core empirical research focuses mostly on the years during and immediately following World War II. He begins by assessing the impact of the Good Neigplehbor Policy upon Mexican American and African American civil rights strategies in the 1940s. An outgrowth of the United States' fight against fascism, the Good Neighbor Policy sought strategic hemispheric alliances with Latin American nations. Mexican American civil rights leaders affixed this policy to their civil rights strategy, arguing that domestic treatment of Mexican Americans had significant foreign policy repercussions. In Texas, Mexican American civil rights leaders pushed legislation such as the Caucasian Race Resolution. In the effort to guarantee Mexican Americans fair tre atment based on whiteness, Mexican American civil rights leaders alienated African Americans. Foley contextualizes the Mexican impulse toward whiteness by reviewing the long tradition in Mexico and other Latin American nations of fetishizing white skin, embodied mostly in Mexico's post-1810 Revolutionary idea of mestizaje and the Mexican philosopher José Vasconcellos' notion of la raza cósmica. Accounting for what Foley calls Mexico’s “racial amnesia," Mexico's racial thinking excluded African and Asian origin citizens from Mexican racial and national identity (11).

Racial solidarity also failed to emerge in America's wartime industries despite the reality that both racial groups faced similar forms of employment discrimination. Mexican Americans chose not to place themselves on the wrong side of the color line with African Americans in charting a civil rights course. Foley highlights one poignant example to support his thesis, when Fair Employment Practices Commission (FEPC) regional director Carlos Castañeda pressed the Oil Workers International Union (OWIU) to abandon race-based job classifications, as well as the practice of requiring Mexican workers to share work accommodations with African Americans. According to Castañeda, the OWIU violated Mexican labourers' civil rights and Texas state law by denying them equal rights guaranteed by a white racial identity, whether they were citizens or contract workers. Such strategic decision-making, even within a civil rights body such as the FEPC, tempered racial alliances during the formative years of civil rights struggles in the United States.

Nowhere more obvious was a failure of Black-Brown racial solidarity 
than in the effort to end school segregation. Foley's third chapter chronicles relations, or lack thereof, between Mexican American and African American attorneys and civil rights advocates between the landmark legal cases of Mendez v. Westminster (1947) and Brown v. Board of Education (1954). In the Mendez case, Mexican American civil rights leaders fought for equal rights afforded by white racial status, specifically the right not to be segregated in so-called Mexican schools. Correspondence between Mexican American civil rights leadership and African American attorneys, including later US Supreme Court Justice Thurgood Marshall, indicates that Mexican Americans narrowly cleaved to a legal challenge to segregation that endorsed the separate but equal doctrine for Black Americans, but not Mexican Americans. Middle-class Mexican American leadership according to Foley lacked the race consciousness to join African Americans in a full-frontal assault on the Plessy v. Ferguson doctrine of separate but equal. Mexican Americans felt superior toward both recent Mexican immigrants and African Americans. Association with either group risked a loss of personal, economic and social status gained by claiming a white racial identity.

This book is timely given the contemporary debate on illegal Mexican immigration and its implications on Latinos and African Americans. Racial solidarity is critical to challenge the rising tide of racial legislation reinforcing America's white racial democracy, so well eluded to in Foley's book. Future studies on historical relations between Mexican Americans and African Americans no doubt will more fully contextualize relations between the two racial groups beyond the war years. Scholars will grapple though with Foley's contention that whiteness has determined the boundaries and permeability of American racial solidarity.

Oliver A. Rosales

University of California, Santa Barbara

Daniel Widener, Black Arts West: Culture and Struggle in Postwar Los Angeles (Durham and London: Duke University Press, 2010).

For contemporary scholars of post World War II United States history, the narrative of struggles for social equality follows a now familiar trajectory. Racially marginalized groups, galvanized by the economic and social opportunities of the postwar era, mobilized politically to overtly challenge centuries of American racism; first, by demanding equal inclusion within the system of liberal democracy; and later, once frustrated by the deliberately slow pace of change, grew more radicalized and pushed for a new politics of self-determination. The liberating promise of these social movements was cut short in the 1970s for numerous reasons, not the least of which was the vitriolic backlash against civil rights, the murder of prominent leaders of color, and the commercial appropriation of the era's cultural symbols, which turned signs of committed social activism into fashion state- 